anales de psicología / annals of psychology

2019, vol. 35, no 3 (october), 464-471

http://dx.doi.org/10.6018/analesps.35.3.320441
(C) Copyright 2019: Editum. Servicio de Publicaciones de la Universidad de Murcia. Murcia (Spain) ISSN print edition: 0212-9728. ISSN on line edition (http://revistas.um.es/analesps): 1695-2294.

On line edition License Creative Commons 4.0: BY-NC-ND

\title{
Motivational profiles related to the academic satisfaction of university students
}

\author{
Jorge Vergara-Morales ${ }^{1 *}$, Milenko Del Valle ${ }^{2}$, Alejandro Díaz ${ }^{1}$, Lennia Matos ${ }^{3}$, and María-Victoria Pérez ${ }^{1}$ \\ 1 Programa de Doctorado en Psicologia, Departamento de Psicología, Universidad de Concepción (Chile) \\ 2 Departamento de Ciencias Sociales, Universidad de Antofagasta (Chile) \\ 3 Departamento de Psicología, Pontificia Universidad Católica del Perú (Perú)
}

\begin{abstract}
Título: Perfiles motivacionales relacionados con la satisfacción académica de estudiantes universitarios.

Resumen: Los objetivos del estudio fueron identificar los perfiles motivacionales de estudiantes universitarios y evaluar sus diferencias en cuanto a la satisfacción académica. Los participantes fueron 882 estudiantes con edades comprendidas entre los 17 y 50 años, procedentes de nueve universidades chilenas. Los perfiles motivacionales se identificaron mediante análisis de conglomerados, siguiendo la combinación de métodos jerárquicos y no jerárquicos. El análisis de conglomerados se realizó incluyendo las siguientes variables motivacionales: (1) motivación autónoma, (2) motivación controlada, (3) percepción de apoyo a la autonomía, y (4) percepción de control de la autonomía. Las diferencias entre los perfiles se evaluaron a través de la prueba Anova unifactorial, considerando el cálculo del tamaño del efecto y el análisis post-hoc de Games-Howell. Los resultados del análisis de conglomerados apoyaron una solución de cuatro perfiles motivacionales: mala calidad ( $n=167)$, baja cantidad $(n=144)$, buena calidad ( $n=$ $333)$, y alta cantidad $(n=238)$. Además, los estudiantes agrupados en los perfiles con mayores niveles de autonomía para el aprendizaje, presentaron los niveles más altos de satisfacción académica. Como conclusión, se destaca la importancia que tienen los factores motivacionales para facilitar el desarrollo del bienestar de los estudiantes universitarios.

Palabras clave: motivación autónoma, motivación controlada, estilo motivacional docente, satisfacción académica, análisis de conglomerados.
\end{abstract}

\section{Introduction}

In the field of higher education, the systematic study of learning processes has allowed the development of current educational trends focused on "favoring and enhancing the development of skills and aptitudes that allow the student to develop and adapt to the demands of a society in continual change" (Moreno-Murcia \& Silveira, 2015, p. 170). Thus, the concern "to promote discourses and practices that establish the basis for critical and reflexive thinking that allows understanding and performance in today's society" (Ventura, 2011, p. 143), has been recognized. This has influenced the advancement of a teaching-learning environment oriented towards the development of cognitive factors, together with motivational factors (Moreno-Murcia \& Silveira, 2015), with the purpose of achieving an integral formation of students (García, 2012). Previous studies indicate that motivation represents an indispensable part in the development of learning processes since it activates behavior towards achievement of academic goals (Leal, Miranda \& Souza, 2013; Maieski, Oliveira, Beluce \& Rufini, 2017; Pourfeiz, 2016). Therefore, the motivation constitutes a psychological process that influ-

* Correspondence address [Dirección para correspondencia] Jorge Vergara-Morales. Departamento de Psicología, Facultad de Ciencias Sociales, UdeC. Barrio Universitario s/n, Concepción (Chile).

E-mail: jorvergara@udec.cl

(Article received: 05-02-2018; revised: 09-07-2018; accepted: 11-07-2018)
Abstract: The aims of the study were to identify the motivational profiles of university students and to assess their differences according to the academic satisfaction. The participants were 882 students aged 17 to 50 , from nine Chilean universities. Motivational profiles were identified by cluster analysis, following the combination of hierarchical and non-hierarchical methods. The cluster analysis was perform including the following motivational variables: (1) autonomous motivation, (2) controlled motivation, (3) perception of autonomy support, and (4) perception of autonomy control. The differences between the profiles were assessed through the one way Anova test, considering the effect size calculation, and the Games-Howell post-hoc test. The cluster analysis results supported a four motivational profiles solution: poor quality $(n=167)$, low quantity $(n=144)$, good quality ( $=333)$, and high quantity $(n=238)$. Moreover, students grouped into profiles with higher levels of autonomy for learning, presented the highest levels of academic satisfaction. In conclusion, the importance of motivational factors to facilitate the development of university students' wellbeing is highlighted.

Keywords: autonomous motivation, controlled motivation, teachers' motivating style, academic satisfaction, cluster analysis.

ences the students' well-being as well as the success and the academic failure (Chang, Lee, Byeon \& Lee, 2015; Chen et al., 2015; Gillet, Lafrenière, Huyghebaert \& Fouquereau, 2015; Pereira, 2015; Valenzuela, Valenzuela, Silva-Peña, Gómez \& Precht, 2015; Wash, Karbash, Ruffing, Brünken \& Spinath, 2016).

More and more studies are based on the SelfDetermination Theory (SDT, Deci \& Ryan, 2000) to examine the influence of motivational factors on the development of educational processes since it allows the analysis of different types of motivation that vary according to the degree of autonomy achieved by students, and also considers the interaction with the teaching environment. From the SDT perspective, the motivation is described as a continuous gradient in which different types of behavior regulation develop according to the perceived locus of causality (Turban, Hoon, Brown \& Sheldon, 2007). Thus, when students perceive academic actions as a result of their own determinants, their behavior is oriented through a perceived locus of internal causality from which two types of regulation emerge: (1) intrinsic, characterized by behavior based on engagement, interest, and pleasure inherent to the development of academic activities (Howard, Gagné \& Bureau, 2017), and (2) identified, referring to behavior that is accepted, valued, and considered as personally important (Litalien et al., 2017). These types of regulation are identified as subcomponents of autonomous motivation, defined "as the quality and intensity of one's en- 
ergies driven by the self (autonomous)" (Maulana, HelmsLorenz \& van de Grift, 2016, p. 239).

On the other hand, when students perceive academic actions as a result of external factors, behavior is oriented through a perceived locus of external causality from which two types of regulation become apparent: (1) introjected, referring to behavior driven by avoiding feelings of guilt or shame, or to exalt the ego, and (2) external, referring to behavior driven by receiving rewards or avoiding punishment (Litalien et al., 2017). These types of regulation are identified as subcomponents of controlled motivation, which is observed when behavior is based on obligation, reinforcement, or some other cause with an external reference (Ryan \& Deci, 2008).

From the SDT perspective, the motivating style that the teacher uses during academic activities represents a fundamental aspect to develop the students' autonomy in the learning process. Indeed, autonomy is a psychological process that encourages the interaction of students with the teaching environment in order to achieve experiences of growth and well-being (Reeve, 2010). A teaching environment that facilitates the development of autonomy is constructed through an interpersonal teaching behavior that stimulates the students' internal motivational resources, it uses a flexible language, provides clarifying arguments, and also recognizes and accepts students' negative affect (Shih, 2013). On the other hand, a teaching environment that hinders the development of student autonomy involves an interpersonal teaching behavior that promotes a prescribed way of thinking, feeling, or behaving. This creates a learning context in which teachers control the autonomy of the students through the use of extrinsic incentive and pressure to participate in academic activities (Núñez, Fernández, León \& Grijalvo, 2015).

Therefore, teachers' motivating styles are two parallel motivational processes that guide the behavior of people. On the one hand, the motivating style that supports autonomy promotes the bright side of motivation since it facilitates satisfaction of the student's basic psychological needs leading to a greater engagement towards learning goals. On the other hand, the motivating style that controls autonomy promotes the dark side of motivation since it stimulates frustration of basic psychological needs leading to greater demotivation. More specifically, while a teacher who supports autonomy is interested in how students learn, to frustrate the development of autonomy is not enough for teachers to present a low level of autonomy support, rather it is necessary that they adopt a controlling motivating style (Cheon, Reeve, Song, 2016; Haerens, Aelterman, Vansteenkiste, Soenens \& Van Petegem, 2015; Vansteenkiste \& Ryan, 2013).

Different types of motivation towards learning activities are established through the relationship of students with the motivational characteristics of the teaching environment, in which autonomous and controlled motivation can coexist in the development of academic tasks (Moreno-Murcia \& Silvera, 2015). Hence, current studies have emphasized the combined analysis of different types of motivation with the purpose of identifying groups of students with distinct motivation profiles (Boiché \& Stephan, 2014; Valle et al., 2013; Valle et al., 2015). Therefore, "the analysis of clusters is especially relevant when it is intended to identify the profiles of natural origin or groups of students within a sample that have similar patterns for the scores of determined variables" (Sánchez-Oliva, Leo, Amado, Pulido-González \& GarcíaCalvo, 2015, p. 158).

Results from different studies have shown the existence of four motivational profiles based on the quantity and quality of motivation (Kusurkar, Croiset, Galindo-Garré \& Ten Cate, 2013; Sánchez et al., 2015; Rothes, Lemos \& Gonçalves, 2017; Ullrich-French \& Cox, 2009; Vansteenkiste, Soenens, Sierens, Luyckx \& Lens, 2009; Wormington, Corpus \& Anderson, 2012). Regarding the quality of motivation, a profile called good quality has been identified and is characterized by showing high levels of autonomous motivation and low levels of controlled motivation. This profile has been positively related to adaptive patterns such as effort and well-being, and also to positive levels of academic performance (Franco, Coterón, Martínez \& Brito, 2017). On the contrary, the existence of a profile known as poor quality has been identified has having characteristics related to low levels of autonomous motivation and high scores for controlled motivation (Haerens, Kirk, Cardon, Bourdeaudhuij, \& Vansteenkiste, 2010). This profile has been positively related to maladaptive variables such as boredom and disinterest for academic activities (Sánchez-Oliva et al., 2015). Regarding profiles based on the quantity of motivation, a profile known as high quantity is characterized by students who show high scores for both autonomous and controlled motivation. Opposite to this profile is one identified as low quantity, which is characterized by low scores on all motivational variables (Ullrich-French \& Cox, 2009).

Concerning the method for developing motivational profiles, some studies have used only autonomous and controlled motivation (Haerens et al., 2010; Vansteenkiste et al., 2009), whereas other studies have included variables such as basic psychological needs (Sánchez et al., 2015) and the perception of autonomy support (Granero-Gallegos, BaenaExtremera, Sánchez-Fuentes \& Martínez-Molina, 2014). However, no studies have been done that consider the student's perception of motivational teaching styles that support or control the development of autonomy towards learning. Although different types of motivation are developed through interaction with the motivating styles that teachers establish during the teaching-learning process, we decided to study the formation of motivational profiles, including both autonomous and controlled motivation, as well as the student's perception regarding the support and control of autonomy employed by the teachers during academic activities.

In addition, we analyzed the differences between motivational profiles in relation to academic satisfaction since this variable represents a measure of well-being that is strongly associated with the quality of learning (Ramos et al., 2015) 
and is proposed as a "cognitive component of psychological well-being that refers to the assessments that people make when comparing their aspirations with their achievements" (Medrano \& Pérez, 2010, p. 6). It can be defined as "the well-being and enjoyment that students perceive in their experiences within the academic role" (Medrano, Fernández \& Pérez, 2014, p. 545). Therefore, the aims of this study were to identify the motivational profiles of university students and to assess their differences according to the academic satisfaction. Based on our aims, the first working hypothesis claims the identification of four motivational profiles: poor quality, low quantity, good quality, and high quantity. Finally, the second hypothesis asserts that the motivational profile with the highest degree of autonomy for learning displays the highest level of academic satisfaction.

\section{Method}

\section{Participants}

882 first year university students from nine universities located in the north and center-southern part of Chile participated in the study. $62.4 \%$ were woman $(n=550)$ and $37.6 \%$ were men $(n=332)$, and the range of ages varied between 17 and 50 years old, with an average age of 20.86 years $(S D=$ 4.13). With respect to the type of university, $53.5 \%$ of the participants studied at a university pertaining to the National Council of public universities $(n=472)$, and $46.5 \%$ studied at a private university $(n=410)$. Regarding the type of university programmes that the participants were studying at the time, $49.5 \%$ were doing their undergraduate studies in Social Sciences $(n=437), 26.6 \%$ in the area of Engineering $(n=$ 235), $19.2 \%$ in the area of Medical Sciences and Health $(n=$ $169), 2.4 \%$ in the area of Agricultural Sciences $(n=21)$, and $2.3 \%$ in the area of Natural Sciences $(n=20)$. The selection of participants was made by non-probability sampling of an incidental type based on the choice of intact groups.

\section{Measures}

Autonomy Support Scale (short version): This instrument is based on the Learning Climate Questionnaire (LCQ; Williams \& Deci, 1996), whose model of unifactorial measurement gives adequate psychometric properties, both in its long version $\left(\mathrm{S}-\mathrm{B} \chi^{2}=387.09, p=.01 ; \mathrm{RMSEA}=.08\right.$; $\mathrm{TLI}=$ .94; CFI = .92; SRMR = .04; $\alpha=.95 ;$ Núñez, León, Grijalvo $\&$ Martín-Albo, 2012) and its short version (S-B $\chi^{2}=26.41, p$ $=.01 ; \mathrm{RMSEA}=.10 ; \mathrm{TLI}=.96 ; \mathrm{CFI}=.98 ; \mathrm{SRMR}=.02 ; \alpha$ $=.91$; Núñez et al., 2012). The short version consists of six items that are grouped into a single factor that measures the perception of the degree of which the teacher supports the development of student autonomy (e.g. "I feel that my teacher understands me"). In this study, we used a version adapted to Spanish (Matos, Reeve, Herrera \& Claux, 2018) in which the items were answered on a Likert scale 7-points that ranged from "totally disagree" (1) to "totally agree" (7).
Autonomy Control Scale: This instrument is based on the Teacher Control Questionnaire (TCQ; Jang, Reeve, Ryan \& Kim, 2009) that has been used successfully in previous studies and shows adequate levels of validity and internal consistency (Cheon et al., 2016; Reeve \& Tseng, 2011). It consists of four items grouped into a single factor that measures the perception of the degree of which the teacher hinders the development of student autonomy (e.g. "My teacher tries to control everything I do). We used a version that was adapted to Spanish (Matos et al., 2018) where items were answered on a Likert scale 7-points that ranged from "totally disagree" (1) to "totally agree" (7).

Academic Self-Regulation Scale: This instrument is based on an adapted version of the Self-Regulation Questionnaire (SRQ; Ryan \& Connell, 1989) that has been used successfully in previous studies and shows adequate levels of validity and internal consistency (Vansteenkiste, Lens, De Witte \& Feather, 2005; Vansteenkiste et al., 2009; Vansteenkiste et al., 2012). It is composed of 16 items that measure the reasons for getting involved in academic activities. The items are divided into four factors: (a) intrinsic regulation (4 items, e.g. "Because it's fun"), (b) identified regulation (4 items, e.g. "Because I want to learn new things"), (c) introjected regulation (4 items, e.g. "Because I would feel guilty if I didn't study"), and (d) external regulation (4 items, e.g. "Because I'm supposed to do so"). A version adapted to Spanish was used (Matos, Herrera \& Gargurevich, 2017) that incorporated measures for autonomous and controlled motivation.

These measurements were done using the exploratory factor analysis with PROMAX rotation which demonstrated that the scores for all the items of autonomous motivation had factor loads $\geq .40$ in the first component, while all items for controlled motivation had factorial loads $\geq .40$ in the second factor. The factorial solution explained $48 \%$ of the total variance. No cross over in the charges were found because the motivation measures were not significantly related (Vansteenkiste et al., 2009).

Autonomous motivation was calculated by averaging the sub-component scores for intrinsic and identified regulation. Controlled motivation was calculated by averaging the subcomponent scores for introjected and external regulation. The items were answered on a Likert scale 7-points that ranged from "totally disagree" (1) to "totally agree" (7).

Academic Satisfaction Scale: This instrument consists of 7 items that constitute a single factor that measures the wellbeing and enjoyment that students perceive in relation to their learning experience (e.g. "I enjoy my classes most of the time") (Lent, Singley, Sheu, Schmidt, \& Schmidt, 2007). An adapted version was used in Chilean university context, which showed a unifactorial measurement model with adequate psychometric properties $\left(\chi^{2}=14.29, p>.05\right.$; CFI $=$ .99; TLI = .99; RMSEA = .04; FC = .93) (Vergara-Morales, Del Valle, Díaz \& Pérez, 2018). The items were answered on a Likert scale 7-points that ranged from "totally disagree" (1) to "totally agree" (7). 


\section{Procedure}

This study was done following the ethical principles outlined for research with human subjects (Acevedo, 2002). Once the necessary authorizations were obtained for the students to participate in the study, data collection was done in the classroom by a previously trained professional. The data collection process followed the ethical guidelines of the American Psychological Association (APA).

\section{Data Analyses}

The descriptive analysis was performed by calculating the mean, the standard deviation, and the $\mathrm{Z}$ scores. The internal consistency of the scale scores was evaluated using the Cronbach's $\alpha$ coefficient considering a lower limit of $\alpha=.70$ to identify an acceptable reliability (Kaplan \& Saccuzzo, 2006). The correlation between variables was evaluated using Pearson's correlation coefficient.

Motivational profiles were analyzed using a combination of hierarchical and non-hierarchical cluster methods (Hair, Anderson, Tatham \& Black, 1998). This type of analysis permits "the detection and description of subgroups of subjects or homogeneous variables based on the observed values within an apparently heterogeneous set" (Vilà-Baños, RubioHurtado, Berlanga-Silvente \& Torrado-Fonseca, 2014, p. 114). Ward's hierarchical method was used to identify the optimal number of clusters based on the calculation of the squared Euclidean distance between the standardized motivational data. This procedure minimizes the distance between individual data points within a group avoiding the formation of extended chains (Gómez-López, GraneroGallegos, Baena-Extremera \& Abraldes, 2014). The decision about the adequate number of groups was based on the dendrogram and the theoretical support of the variables.

We also used the non-hierarchical method of K-means cluster analysis to compare the results of the group obtained with the hierarchical method. This procedure reassigns the cases to the groups until reaching the maximum homogeneity within the groups (Hair, Black, Babin \& Anderson, 2009). The correlation between the results of the hierarchical and non-hierarchical analysis was evaluated using Cramer's V considering a coefficient of $>.30$ to identify an appropriate association (Martinic \& Villalta, 2015). Motivational profiles were defined based on the following variables: (1) perception of autonomy support; (2) perception of autonomy control; (3) autonomous motivation; and (4) controlled motivation.

Finally, differences between motivational profiles in terms of academic satisfaction were evaluated using the unifactorial ANOVA statistical test, with application of the Games-Howell post-hoc test because it estimates the differences between the means of each group when homogeneity in the variances is not met (Martinic \& Villalta, 2015). In addition, the effect size was identified $(f)$ according to the following classification: (1) small effect $=.10$; (2) medium effect $=.25$; and (3) large effect $=.40$ (Cárdenas \& Arancibia, 2014).

\section{Results}

\section{Descriptive and correlational analyses}

Table 1 shows the descriptive statistics for each of the variables analyzed. The results demonstrate that academic satisfaction, autonomous motivation, and support for autonomy perceived by the students had the highest mean values. On the other hand, controlled motivation and the perception of autonomy control showed the lowest values. Furthermore, an adequate reliability for the scores was identified since the values for Cronbach's $\alpha$ coefficient were higher than the recommended lower limit.

Regarding the bivariate correlations, the results indicated that the perception of autonomy support had a positive and significant relationship with autonomous motivation $(r=.34$, $p<.01)$ and academic satisfaction $(r=.58, p<.01)$. On the other hand, autonomy control perceived by the students had a positive and significant relationship with controlled motivation $(r=.27, p<.01)$. Moreover, it showed a negative and significant relationship with perception of autonomy support $(r=-.28, p<.01)$, autonomous motivation $(r=-.13, p<.01)$ and academic satisfaction $(r=-.22, p<.01)$ (see table 1$)$.

Table 1. Descriptive statistics, Cronbach's $\alpha$ and correlation between variables.

\begin{tabular}{|c|c|c|c|c|c|c|c|c|}
\hline Variables & $M$ & $S D$ & $\alpha$ & 1 & 2 & 3 & 4 & 5 \\
\hline 1. Autonomy support & 5.55 & 1.09 & .87 & 1.00 & $-.28^{* *}$ & $.34^{* *}$ & $-.17^{* *}$ & $.58^{* *}$ \\
\hline 2. Autonomy control & 2.98 & 1.29 & .70 & & 1.00 & $-.13^{* *}$ & $.27^{* *}$ & $-.22^{* *}$ \\
\hline 3. Autonomous motivation & 5.64 & 1.11 & .89 & & & 1.00 & $-.15^{* *}$ & $.71^{* *}$ \\
\hline 4. Controlled motivation & 2.80 & 1.20 & .80 & & & & 1.00 & $-.20^{* *}$ \\
\hline 5. Academic satisfaction & 5.90 & 1.04 & .91 & & & & & 1.00 \\
\hline
\end{tabular}
Note. ${ }^{* *} p<.01$

These results demonstrate that while the perception of autonomy support increased, autonomous motivation and academic satisfaction of the university students also increased. On the contrary, as the perception of autonomy control increased, autonomous motivation and academic satisfaction decreased.

\section{Cluster Analysis}

Figure 1 shows the dendrogram illustrating the solution of clusters obtained from the application of Ward's hierarchical method. Based on the reading of the dendrogram and on the theoretical sustenance of the variables, the structure 
formed by the four clusters (poor quality, low quantity, high quantity, and good quality) was chosen as the most convenient solution.

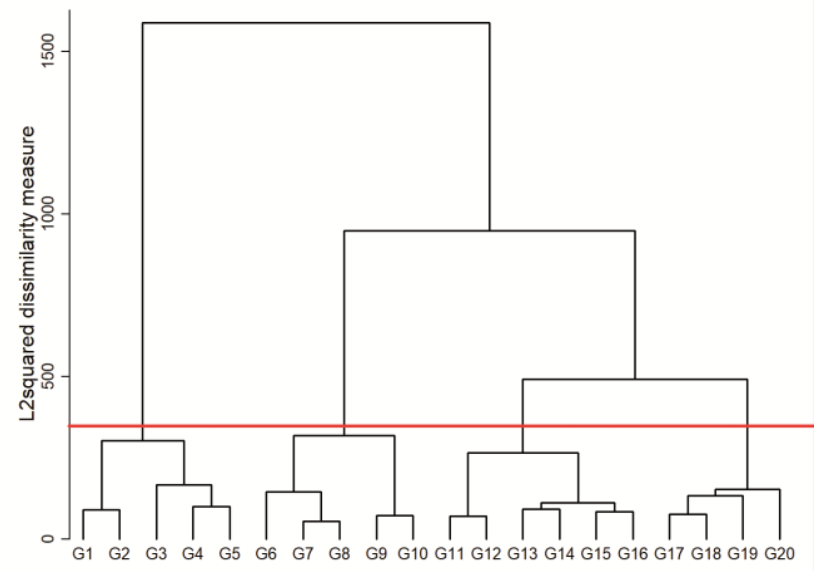

Figure 1. Ward's hierarchical method dendrogram

Figure 2 shows the motivational profiles identified by the non-hierarchical method of K-means, considering the solution for the four groups suggested from the hierarchical cluster analysis. The results are in agreement with the following previously inferred clusters: (a) poor quality motivation group ( $n=167$ students), with relatively high scores in controlled motivation and perception of autonomy control, but relatively low scores in autonomous motivation and perception of autonomy support; (b) low quantity motivation group ( $n=$ 144), with low scores for all motivational variables; (c) good quality motivation group ( $n=333$ ), with relatively high scores in autonomous motivation and perception of autonomy support, but relatively low scores in controlled motivation and perception of autonomy control; (d) high quantity motivation group $(n=238)$, with high scores for all motivational variables, predominantly for controlled motivation and perception of autonomy control for learning (see figure 2).

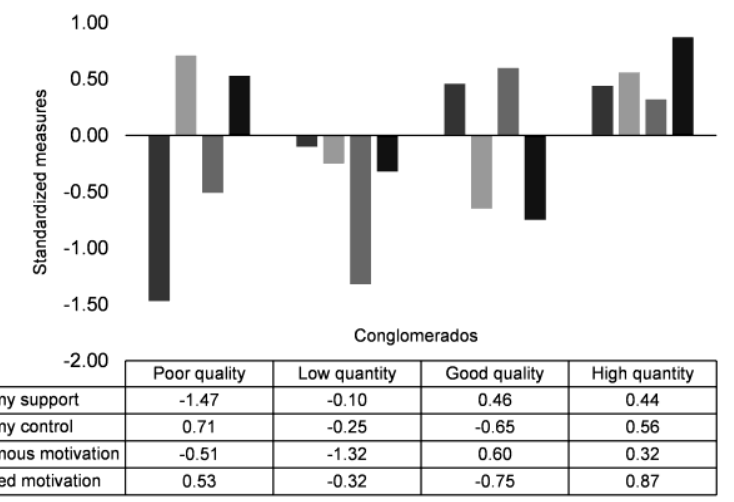

Figure 2. Motivational profiles.

Finally, an acceptable association was found between the number of clusters using hierarchical and non-hierarchical analyses as determined by the value of Cramer's V coefficient $(\mathrm{V}=.78)$ which was higher than the recommended minimum value. Therefore, the degree of similarity between the results obtained with Ward's and K-means methods was verified.

\section{Analysis of differences}

The results show statistically significant differences in academic satisfaction according to the motivational profiles, with a medium effect size (see table 2). In addition, we found that while the motivational profiles implied a greater degree of autonomy for learning, the levels of academic satisfaction were increased. Thus, students with a motivation profile corresponding to good quality exhibited the highest values for academic satisfaction, followed by the motivation profile group corresponding to high quantity. The differences between the scores of these groups were statistically significant. On the contrary, students having a poor quality motivation profile showed the lowest values for academic satisfaction, followed by the low quantity motivation profile group. No statistically significantly differences were found in the scores between these two groups.

Table 2. Z scores and analysis of differences according to motivational profiles.

\begin{tabular}{|c|c|c|c|c|c|c|c|}
\hline & $\begin{array}{l}\text { Poor quality } \\
\quad(n=167)\end{array}$ & $\begin{array}{l}\text { Low quantity } \\
\quad(n=144)\end{array}$ & $\begin{array}{l}\text { Good quality } \\
\quad(n=333)\end{array}$ & $\begin{array}{l}\text { High quantity } \\
\quad(n=238)\end{array}$ & $F_{(3,878)}$ & $f$ & Post-hoc \\
\hline Academic satisfaction & -.92 & -.66 & .54 & .29 & $171, p<.01$ & .37 & $\begin{array}{c}1<2 ; 1<3^{*} ; 1>4^{*} \\
2<3^{*} ; 2<4^{*} \\
3>4^{*}\end{array}$ \\
\hline
\end{tabular}

\section{Discussion and Conclusions}

The aims of the study were to identify the motivational profiles of university students and to assess their differences according to the academic satisfaction. The results demonstrated that the four profile solution described in a more parsimonious way the variance among the scores of the measured motivational variables. The composition of the groups was found to be quite heterogeneous with respect to their motivational profiles because they differed in terms of quantity and quality of motivation, therefore, they were grouped in the following manner: (a) poor quality, (b) high quantity, (c) good quality, and (d) low quantity. These results are in agreement with findings from studies done by Kusurkar et al., 2013; Sánchez et al., 2015; Rothes et al., 2017; UllrichFrench \& Cox, 2009; Vansteenkiste et al., 2009 and Worm- 
ington et al., 2012. Therefore, there is sufficient evidence to support the first hypothesis of this study.

The results suggest that the interaction that the student has with the teachers' motivating style is important because the group that had the highest levels of autonomous motivation was the one where the perception of a style that supports the development of autonomy for learning predominated. In other words, they had the highest levels of engagement, interest, and persistence to participate in academic activities. On the other hand, the group who perceived a teachers' motivating style that controls the development of autonomy to learn demonstrated the highest levels of controlled motivation. That is to say, they had conduct associated with maladaptive behaviors such as boredom and disinterest in doing academic tasks. Thus, it is important that teachers design learning environments based on academic activities that promote a student's sense of choice and personal initiative, because not only does it facilitate acceptance for learning tasks, but also stimulates engagement, interest, and pleasure inherent to the development of academic activities.

Furthermore, the results indicate that while motivational profiles implied a greater degree of autonomy for learning, the levels of academic satisfaction were increased. Indeed, although good quality and high quantity motivation groups showed the highest values, significant differences were observed in favor of the first group. Therefore, the data suggest that the high quantity motivation group had lower values because it had the additional presence of controlled motivation and perception of autonomy control, together with autonomous motivation and perception of autonomy support, which implied a decrease in the levels of academic satisfaction in the students. These results agree with those from Vansteenkiste et al., 2009, Moreno-Murcia \& Silveira, 2015 and Sánchez et al., 2015; since we observed that while the students increased their levels of autonomy to learn, greater

\section{References}

Acevedo, I. (2002). Aspectos éticos en la investigacion cientifica. Ciencia y Enfermería, 8(1), 15-18. doi: /10.4067/S0717-95532002000100003

Boiché, J., \& Stephan, Y. (2014). Motivational profiles and achievement: A prospective study testing potential mediators. Motiv Emot, 39(1), 79-92. doi:10.1007/s11031-013-9361-6

Cárdenas, M., \& Arancibia, H. (2014). Potencia estadística y cálculo del tamaño del efecto en $G^{*}$ Power. Complementos a las pruebas de significación estadística y su aplicación en Psicología. Salud \& Sociedad, 5(2), 210-224. Recuperado http:/ / www.redalyc.org/articulo.oa?id $=439742475006$

Chang, E., Lee, A., Byeon, E., \& Lee, S. M. (2015). Role of motivation in the relation between perfectionism and academic burnout in Korean students. Personality and Individual Differences, 82, 221-226. doi:10.1016/j.paid.2015.03.027

Chen, B., Vansteenkiste, M., Beyers, W., Boone, L., Deci, E., Van der Kaap-Deeder,...Verstuyf, J. (2015). Basic psychological need satisfaction, need frustration, and need strength across four cultures. Motivation and Emotion, 39(2), 216-236. doi:10.1007/s11031-014-9450-1

Cheon, S., Reeve, J., \& Song, Y-G. (2016). A Teacher-Focused Intervention to Decrease PE Students' Amotivation by Increasing Need Satisfaction adaptive consequences were attained in the context of academic activities. Hence, there is sufficient evidence to support the second working hypothesis.

Finally, the results of the study support the distinction between the quality and quantity of motivation by which it is possible to observe the motivational behavior of students with greater clarity, since it not only focuses on the intensity of behavior regulation, but also in its direction or course. Furthermore, the results show the relevance that the type of motivation has and the perception of the teachers' motivating style of teaching in order to promote the development of different degrees of academic satisfaction associated with the learning experience. This can contribute to the development of teacher training programs aimed at improving teacherstudent interaction, since promoting motivating styles that support student autonomy implies not only the establishment of autonomous motivation for learning, but also the development of adaptive behaviors in the teaching context.

One of the limitations of the study is the cross-sectional nature of the data. Because motivation is a psychological process that varies constantly, it is important that future studies incorporate the development of longitudinal type designs. Another limitation of the study deals with the measurement of the teaching motivating style because it was only observed through the perception of the students. Therefore, it is important that future studies include measurements from the perspective of teachers.

Acknowledgments.- The first author thanks CONICYT (Chile) for the research grant (No. 21150419) granted for doctoral studies.

Note: This article is part of the CONICYT project, FONDECYT $\mathrm{N}^{\circ} 1161502$ entitled "Explanatory model of the permanence and abandonment of university studies, based on cognitive-motivational processes".

and Decreasing Need Frustration. Journal of Sport \& Exercise Psychology, 38, 217-235. doi:10.1007/s11031-014-9450-1

Deci, E., \& Ryan, R. (2000). The "what" and "why" of goal pursuits: Human needs and the self-determination of behaviour. Psychological Inquiry, 11(4), 227-268. doi:10.1207/S15327965PLI1104_01

Franco, E., Coterón, J., Martínez, H., \& Brito, J. (2017). Perfiles motivacionales en estudiantes de educación física de tres países y su relación con la actividad física. Suma Psicológica, 24(1), 1-8. doi:10.1016/j.sumpsi.2016.07.001

García, J. (2012). La educación emocional, su importancia en el proceso de aprendizaje. Revista Educación, 36(1), 97-109. doi:10.15517/revedu.v36i1.455

Gillet, N., Lafrenière, M. A., Huyghebaert, T., \& Fouquereau, E. (2015). Autonomous and controlled reasons underlying achievement goals: Implications for the $3 \times 2$ achievement goal model in educational and work settings. Motivation and Emotion, 39(6), 858-875. doi:10.1007/s11031-015-9505-y

Gómez-López, M., Granero-Gallegos, A., Baena-Extremera, A., \& Abraldes, J. A. (2014). Análisis de los perfiles motivacionales y su relación con la importancia de la educación física en secundaria. Revista 
Iberoamericana de Diagnóstico y Evaluación - e Avaliação Psicológica, 2(38), 11Recuperado

http:/ / www.redalyc.org/articulo.oa?id=459645434002

Granero-Gallegos, A., Baena-Extremera, A., Sánchez-Fuentes, J. A., \& Martínez-Molina, M. (2014). Perfiles motivacionales de apoyo a la autonomía, autodeterminación, satisfacción, importancia de la educación física e intención de práctica física en tiempo libre. Cuadernos de Psicología del Deporte, 14(2), 59-70. doi:10.4321/S157884232014000200007

Haerens, L., Kirk, D., Cardon, G., de Bourdeaudhuij, I., \& Vansteenkiste, M. (2010). Motivational profiles for secondary school physical education and its relationship to the adoption of a physically active lifestyle among university students. European Physical Education Review, 16(2), 117-139. doi:10.1177/1356336X10381304

Haerens, L., Aelterman, N., Vansteenkiste, M., Soenens, B., \& Van Petegem, S. (2015). Do perceived autonomy-supportive and controlling teaching relate to physical education students' motivational experiences through unique pathways? Distinguishing between the bright and dark side of motivation. Psychology of Sport and Exercise, 16, 26-36. doi:10.1016/j.psychsport.2014.08.013

Hair, J. F., Anderson, R. E., Tatham, R. L., \& Black, W. C. (1998). Multivariate Data Analysis. New Jersey, NJ: Prentice-Hall.

Hair, J. F., Black, W. C., Babin, B. J., \& Anderson, R. E. (2009). Multivariate Data Analysis. Upper Saddle River, NJ: Prentice Hall.

Howard, J., Gagné, M., \& Bureau, J. (2017). Testing a Continuum Structure of Self-Determined Motivation: A Meta-Analysis. Psychological Bulletin, 143(12), 1346-1377. doi:10.1037/bul0000125

Jang, H., Reeve, J., Ryan, R. M., \& Kim, A. (2009). Can self-determination theory explain what underlies the productive, satisfying learning experiences of collectivistically-oriented South Korean adolescents? Journal of Educational Psychology, 101(3), 644-661. doi:10.1037/a0014241

Kaplan, R., \& Saccuzzo, D. (2006). Pruebas psicológicas. Principios, aplicaciones y temas. México: Thomson.

Kusurkar, R., Croiset, G., Galindo-Garré, F., \& Ten Cate, O. (2013). Motivational profiles of medical students: Association with study effort, academic performance and exhaustion. BMC Medical Education, 13(87), 1-8. doi:10.1186/1472-6920-13-87

Leal, E. A., Miranda, G. J., \& Souza, C. R. (2013). Self-determination theory: an analysis of student motivation in an accounting degree program. Revista Contabilidade \& Finanças, 24(62), 162-173. doi:10.1590/S1519-70772013000200007

Lent, R., Singley, D., Sheu, H., Schmidt, J., \& Schmidt, L. (2007). Relation of social-cognitive factors to academic satisfaction in engineering students. Journal of Career Assessment, 15(1), 87-97. doi:10.1177/1069072706294518

Litalien, D., Morin, A., Gagné, M., Vallerand, R., Losier, G., \& Ryan, R. (2017). Evidence of a continuum structure of academic selfdetermination: A two-study test using a bifactor-ESEM representation of academic motivation. Contemporary Educational Psychology, 51, 67-82. doi:10.1016/j.cedpsych.2017.06.010

Maieski, S., Oliveira, K. L., Carvalho, A., \& Rufini, S. E. (2017). Motivação de alunos do ensino fundamental: estudo de duas realidades culturais. Psicologia Escolar e Educacional, 21(3), 601-608. doi:10.1590/21753539/2017/0213111129

Martinic, S., \& Villalta, M. (2015). La gestión del tiempo en la sala de clases y los rendimientos escolares en escuelas con jornada completa en Chile. Perfiles Educativos, 37(147), 28-49. Recuperado de http:/ / www.redalyc.org/articulo.oa?id=13233749003

Matos, L., Herrera, D., \& Gargurevich. R. (2017). Instructional styles, students needs and engagement. Manuscrito en preparación.

Matos, L., Reeve, J., Herrera, D., \& Claux, M. (2018). Students' Agentic Engagement Predicts Longitudinal Increases in Perceived AutonomySupportive Teaching: The Squeaky Wheel Gets the Grease. The Journal of Experimental Education. doi:10.1080/00220973.2018.1448746

Maulana, R., Helms-Lorenz, M., \& van de Grift, W. (2016). The role of autonomous motivation for academic engagement of indonesian secondary school students: A multilevel modelling approach. En R. B. King \& A. B. I. Bernardo (Eds.), The psychology of Asian learners: A festschrift in honor of David Watkins (pp. 237-252). London, UK: Springer.
Medrano, A., \& Pérez, E. (2010). Adaptación de la Escala de Satisfacción Académica a la Población Universitaria de Córdoba. Summa Psicológica UST, 7(2), 5-14. Recuperado de https: / / dialnet.unirioja.es/servlet/articulo?codigo $=3423953$

Medrano, A., Fernández, M., \& Pérez, E. (2014). Computerized Assesment System For Academic Satisfaction (ASAS) for first-year University Student. Electronic Journal of Research in Educational Psychology, 12(2), 541562. doi:10.14204/ejrep.33.13131

Moreno-Murcia, J. A., \& Silveira, Y. (2015). Perfiles motivacionales de estudiantes universitarios. Procesos de estudio y satisfacción con la vida. Revista Electrónica Interuniversitaria de Formación del Profesorado, 18(3), 169-181. doi:10.6018/reifop.18.3.200441

Núñez, J., León, J., \& Grijalvo, F., \& Martín-Albo, J. (2012). Measuring Autonomy Support in University Students: the Spanish Version of the Learning Climate Questionnaire. The Spanish Journal of Psychology, 15(3), 1466-1472. doi:10.5209/rev_SJOP.2012.v15.n3.39430

Núñez, J., Fernández, C., León, J., \& Grijalvo, F. (2015). The relationship between teacher's autonomy support and students' autonomy and vitality. Teachers and Teaching: theory and practice, 21(2), 191-202. doi:10.1080/13540602.2014.928127

Pereira, F. O. (2015). Especificidades do rendimento, aptidão e motivação escolares em alunos com dificuldades de aprendizagem. Psicologia Escolar e Educacional, 19(3), 525-536. doi:10.1590/2175 $3539 / 2015 / 0193889$

Pourfeiz, J. (2016). A Cross-sectional Study of Relationship between Attitudes toward Foreign Language Learning and Academic Motivation. Procedia - Social and Behavioral Sciences, 232, 668-676. doi:10.1016/j.sbspro.2016.10.091

Ramos, A., Tomaschewski, J., Lerch, V., Devos, E., Silva, R., \& Saraiva, S. (2015). Satisfaction with academic experience among undergraduete nursing students. Text Context Nursing, 24(1), 187-195. doi:10.1590/0104-07072015002870013

Reeve, J. (2010). Motivación y emoción. México, Ciudad de México: McGrawHill.

Reeve, J. \& Tseng, C. M. (2011). Cortisol reactivity to a teacher's motivating style: the biology of being controlled versus supporting autonomy. Motiv Emot, 35(1), 63-74. doi:10.1007/s11031-011-9204-2

Rothes, A., Lemos, M., \& Gonçalves, T. (2017). Motivational Profiles of Adult Learners. Adult Education Quarterly, 67(1), 3-29. doi:10.1177/0741713616669588

Rubio-Hurtado, M. J., \& Berlanga-Silvente, V. (2012). Cómo aplicar las pruebas paramétricas bivariadas t de Student y Anova en SPSS. Caso práctico. REIRE, Revista d'Innovació $i$ Recerca en Educació, 5(2), 83-100. https://doi.org/10.1344/reire2012.5.2527

Ryan, R. M., \& Connell, J. P. (1989). Perceived locus of causality and internalization: Examining reasons for acting in two domains. Journal of Personality and Social Psychology, 57, 749-761. doi:10.1037/00223514.57.5.749

Ryan, R. M., \& Deci, E. (2008). Self-Determination Theory: A Macrotheory of Human Motivation, Development, and Health. Canadian Psychology, 49(3), 182-185. doi:10.1037/a0012801

Sánchez-Oliva, D., Leo F., Amado, D., Pulido-González, J., \& GarcíaCalvo, T. (2015). Análisis de los perfiles motivacionales y su relación con los comportamientos adaptativos en las clases de educación física. Revista Latinoamericana de Psicología, 47(3), 156-166. doi:10.1016/j.rlp.2015.06.007

Shih, S. (2013). The effects of autonomy support versus psychological control and work engagement versus academic burnout on adolescents' use of avoidance strategies. School Psychology International, 34(3), 330-347. doi:10.1177/0143034312466423

Turban, D., Hoon, H., Brown, K., \& Sheldon, K. (2007). Antecedents and Outcomes of Perceived Locus of Causality: An Application of SelfDetermination Theory. Journal of Applied Social Psychology, 37(10), 23762404. doi:10.1111/j.1559-1816.2007.00263.x

Ullrich-French, S., \& Cox, A. (2009). Using cluster analysis to examine the combinations of motivation regulations of physical education students. Journal of Sport \& Exercise Psychology, 31(3), 358-379. doi: 10.1123 /jsep.31.3.358 
Valenzuela, J., Valenzuela, C., Silva-Peña, I., Gómez, V., \& Precht, A. (2015). Motivación escolar: Claves para la formación motivacional de futuros docentes. Estudios Pedagógicos (Valdivia), 41(1), 351-361. doi:10.4067/S0718-07052015000100021

Valle, A., Núñez, J. C., Cabanach, R., Rodríguez, S., Rosário, P., \& Inglés, C. J. (2013). Motivational profiles as a combination of academic goals in higher education, Educational Psychology, 35(5), 634-650. doi:10.1080/01443410.2013.819072

Valle, A., Regueiro, B., Rodríguez, S., Piñeiro, I., Freire, C., Ferradças, M., \& Suárez, N. (2015). Perfiles motivacionales como combinación de expectativas de autoeficacia y metas académicas en estudiantes universitarios. European Journal of Education and Psychology, 8(1), 1-8. doi:10.1016/j.ejeps.2015.10.001

Vansteenkiste, M., \& Ryan, R. M. (2013). On psychological growth and vulnerability: basic psychological need satisfaction and need frustration as a unifying principle. Journal of Psychotherapy Integration, 23, 263-280. doi: $10.1037 / \mathrm{a} 0032359$.

Vansteenkiste, M., Sierens, E., Goossens, L., Soenens, B., Dochy, F., Mouratidis, A., . . . Beyers, W. (2012). Identifying configurations of perceived teacher autonomy support and structure: Associations with self-regulated learning, motivation and problem behavior. Learning and Instruction, 22, 431-439. doi:10.1016/j.learninstruc.2012.04.002

Vansteenkiste, M., Soenens, B., Sierens, E., Luyckx, K., \& Lens, W. (2009). Motivational Profiles from a Self-Determination Perspective: The Quality of Motivation Matters. Journal of Educational Psychology, 101(3), 671-688. doi:10.1037/a0015083

Vansteenkiste, M., Lens, W., De Witte, H., \& Feather, N. T. (2005). Understanding unemployed people's job search behaviour, unemployment experience and well-being: A comparison of expectancy-value theory and self-determination theory. British Journal of Social Psychology, 44, 269-287. doi:10.1348/014466604X17641

Ventura, A. (2011). Estilos de aprendizaje y prácticas de enseñanza en la Universidad. Un binomio que sustenta la calidad educativa. Perfiles Educativos, 33, 142-154. Recuperado de http:/ / www.redalyc.org/articulo.oa?id=13221258013

Vergara-Morales, J., Del Valle, M., Díaz, A., Pérez, M. V. (2018). Adaptación de la escala de satisfacción académica en estudiantes universitarios chilenos. Psicología Educativa, 24, 99-106. doi: $10.5093 /$ psed2018a15

Vilà-Baños, R., Rubio-Hurtado, M. J., Berlanga-Silvente, V., \& TorradoFonseca, M. (2014). Cómo aplicar un cluster jerárquico en SPSS. REIRE, Revista d'Innovació $i$ Recerca en Educació, 7(1), 113-127. Recuperado http://diposit.ub.edu/dspace/bitstream/2445/65577/1/628893.pdf

Wach, F. S., Karbach, J., Ruffing, S., Brünken, R., \& Spinath, F. M. (2016). University Students' Satisfaction with their Academic Studies: Personality and Motivation Matter. Frontiers in Psychology, 7(55), 1-12. doi:10.3389/fpsyg.2016.00055

Williams, G. C., \& Deci, E. L. (1996). Internalization of biopsychosocial values by medical students: A test of self-determination theory. Journal of Personality and Social Psychology, 70(4), 767-779. doi:10.1037/00223514.70.4.767

Wormington, S. V., Corpus, J. H., \& Anderson, K. A. (2012). A personcentered investigation of academic motivation and its correlates in high school. Learning and Individual Differences, 22(4), 429-438. doi:10.1016/j.lindif.2012.03.004 